\title{
FLUKTUASI TINGKAT INFLASI, SUKU BUNGA DAN PRODUK DOMESTIK BRUTO TERHADAP TABUNGAN DI INDONESIA TAHUN 2005-2010
}

\author{
Oleh: \\ Dita Kartika Sari \\ Mahasiswa Pascarsarjana Universitas Mulawarman \\ E-mail/No.Hp: ditakar@yahoo.co.id/-
}

\begin{abstract}
The research objective was to determine the progression rate of inflation, interest rates and gross domestic product of the savings from the years 2005-2010, to determine the magnitude of the effect of inflation rates, interest rates and gross domestic product of the savings. Analysis tools used in this study using multiple regression. Analytical results obtained are inflation, interest rates, gross domestic product is jointly affect savings. Based on this research, the implications of this research that the savings are affected by inflation, interest rates (SBI) and gross domestic product (GDP), while the rest is explained by other variables outside the model that is implicitly reflected in the variable.
\end{abstract}

Keywords : Inflation, Interest Rate, Gross Domestic Product, and Saving

\begin{abstract}
Abstrak
Tujuan penelitian adalah untuk mengetahui perkembangan tingkat inflasi, suku bunga dan produk domestik bruto terhadap tabungan dari tahun 2005-2010, untuk mengetahui besarnya pengaruh tingkat inflasi, suku bunga dan produk domestik bruto terhadap tabungan. Alat analisis yang digunakan pada penelitian ini menggunakan regresi berganda. Hasil analisis yang didapat adalah inflasi, suku bunga, produk domestik bruto secara bersama-sama berpengaruh terhadap tabungan. Berdasarkan hasil penelitian, maka implikasi penelitian ini bahwa tabungan dipengaruhi oleh Inflasi, Suku bunga (SBI) dan Produk domestik bruto (PDB), sedangkan sisanya dijelaskan oleh variabel lain diluar model yang secara implisit tercermin pada variabel.
\end{abstract}

Kata Kunci : Inflasi, Suku Bunga, Produk Domestik Bruto, dan Tabungan

\section{PENDAHULUAN}

Saat ini aktivitas manusia yang investasinya. Dengan adanya aktivitas berhubungan dengan menabung menabung maka penabung akan sangatlah penting, adanya tabungan masyarakat maka dana tersebut tidaklah hilang, tetapi dipinjam atau dipakai oleh pengusaha untuk membiayai mendapatkan bunga atas tabungannya sedangkan pengusaha juga akan bersedia membayar bunga tersebut selama harapan keuntungan diperoleh 
dari investasi lebih besar dari yang dibayarkannya. Adanya kesamaan antara tabungan dengan investasi misalnya apabila tabungan meningkat maka pengeluaran investasi juga meningkat adalah sebagai akibat bekerja mekanisme bunga.

Menabung memberikan banyak kemudahan dan manfaat bagi setiap orang. Manfaat bagi kegiatan setiap orang yakni, dapat mengakomodasi uangnya selanjutnya uang tersebut dapat digunakan untuk investasi. Dengan menabung setiap orang dapat merasakan keamanan uangnya terjamin dan tidak perlu takut kehilangan uangnya karena uang tersebut berada didalam suatu lembaga yang resmi, dengan menabung dapat melatih seseorang untuk hidup hemat. Menabung juga dapat meringankan beban seseorang dimasa depan atau pada saat tertentu apabila penabung mengalami kesulitan, maka setiap saat dia dapat mengambil uang sesuai dengan jenis tabungan mana yang telah dipilih oleh penabung. Manfaat tabungan bukan hanya penting bagi penabung tetapi juga bermanfaat bagi negara dan lembaga perbankan karena melalui lembaga perbankan uang tersebut akan terakomodasi sebagai modal yang kemudian dapat digunakan sebagai penawaran kredit kepada pihak investor untuk dapat mengekspansi usahanya. Dari manfaat tabungan diatas orang dengan sendirinya sadar dan mau menyimpan uang di bank.

Tabungan adalah selisih antara pendapatan dan konsumsi. Bunga pada dasarnya berperan sebagai pendorong utama agar masyarakat bersedia menabung. Jumlah tabungan akan ditentukan oleh tinggi rendahnya tingkat bunga. Semakin tinggi suku bunga, akan semakin tinggi pula minat masyarakat untuk menabung, dan sebaliknya. Tinggi rendahnya penawaran dana investasi juga ditentukan oleh tinggi rendahnya suku bunga tabungan masyarakat. Tabungan juga merupakan sumber dana yang cukup besar. Karena tabungan termasuk dalam sumber dana pihak ketiga bagi bank. Aktivitas menabung dipengaruhi oleh faktor-faktor seperti pendapatan, tingkat suku bunga dan tingkat inflasi.

Salah satu daya tarik seseorang untuk menabung adalah suku bunga dan suku bunga ini merupakan faktor yang pertama. Suku bunga itu sendiri ditentukan oleh dua kekuatan, yaitu : penawaran tabungan dan permintaan investasi modal (terutama dari sektor bisnis). Tingkat suku bunga merupakan 
harga dari penggunaan uang atau bisa juga dipandang sebagai sewa atas penggunaan uang untuk jangka waktu tertentu seperti halnya dengan barangbarang lain. Faktor yang mempengaruhi tabungan masyarakat berikutnya adalah inflasi. Inflasi ialah suatu keadaan dimana senantiasa terjadi meningkatnya harga-harga atau suatu keadaan dimana terjadinya penurunan daripada nilai uang yang beredar didalam masyarakat sehingga untuk menghindari keadaan ini akan mengambil jalan pintas dengan mengubah uang kasnya menjadi barang, yakni dengan cara membelanjakan uang kas untuk membeli barang-barang konsumsi, ini berarti akan mengakibatkan permintaan barangbarang dan selanjutnya akan meningkat pula harga barang, oleh karena itu walaupun masyarakat memegang banyak uang namun uang tersebut akan cepat habis karena harga riil daripada barang-barang yang tersedia di pasar juga meningkat, sehingga uang tersebut hanya dapat digunakan oleh setiap orang untuk mengkonsumsi barangbarang daripada hasrat atau keinginan untuk menabung. Realitas ini akan mempengaruhi daya tabung masyarakat, jadi tingkat tabungan akan menurun karena dana masyarakat cenderung digunakan untuk mengkonsumsi barang. Tingkat bunga dan inflasi bersama-sama sangat mempengaruhi masyarakat untuk dapat meningkatkan tabungan. Hal ini dapat kita amati pada kehidupan sehari-hari masyarakat yang selalu mencari informasi mengenai tingkat bunga yang tercipta didalam pasar uang, apabila mereka mengetahui bahwa tingkat bunga yang lebih tinggi maka masyarakat akan lebih mengurangi pengeluarannya untuk mengkonsumsi guna menambah tabungan mereka karena masyarakat mempunyai harapan bahwa uang mereka akan bertambah pada bulan atau tahun berikutnya daripada mereka harus menyimpan uang dirumah. Dan sebaliknya apabila tingkat suku bunga menurun maka masyarakat akan mengurangi tabungan. Hal ini serupa dengan inflasi, apabila inflasi semakin meningkat masyarakat akan menambah permintaan terhadap barang konsumsi, jadi akan menyebabkan tabungan menurun dan sebaliknya apabila kedua faktor tersebut diatas sama-sama terjadi yaitu tingkat suku bunga menurun dan inflasi meningkat maka akan menyebabkan daya tabung masyarakat semakin menurun. 
Faktor lain yang sangat menentukan tabungan adalah pendapatan. Jika semakin tinggi tingkat pendapatannya, maka peluang untuk menabung juga semakin tinggi. Sejalan dengan pemikiran tersebut, bahwa seseorang yang tingkat pendapatannya semakin tinggi maka semakin tinggi pula tingkat tabungannya, karena tabungan merupakan bagian dari pendapatan yang tidak dikonsumsikan. Berdasarkan uraian latar belakang diatas, maka dilakukan penelitian tentang "Fluktuasi Tingkat Inflasi, Suku Bunga, dan Produk Domestik Bruto Terhadap Tabungan di Indonesia Tahun 2005-2010"

\section{METODE PENELITIAN}

Penelitian ini dilaksanakan dengan mengambil objek pada PT. Bank Indonesia, dan Perpustakaan Bank Indonesia Malang. Pemilihan lokasi dilakukan atas pertimbangan dan kesesuaian dengan penelitian karena Bank Indonesia merupakan bank yang mempunyai satu tujuan tunggal, yaitu mencapai dan memelihara kestabilan nilai rupiah.

Jenis penelitian yang digunakan peneliti adalah deskriptif kuantitatif yaitu penelitian yang menggambarkan secara deskriptif perkembangan inflasi, suku bunga, dan pendapatan pada kurun waktu 2005.07-2010.12, kemudian dianalisis menggunakan pendekatan kuantitatif dan perkembangan tabungan pada bank umum dengan standart yang ditetapkan oleh Bank Indonesia.

Seluruh data yang digunakan dalam penelitian ini adalah data time series selama periode tahun 2005.072010.12. Sumber data tersebut diperoleh dari beberapa instansi yang terkait yaitu Bank Indonesia yang telah dipublikasikan lewat media elektronik yaitu internet dengan alamat website resminya www.bi.go.id, www.bps.go.id dan diambil dari Statistik Ekonomi Indonesia yang dikeluarkan oleh Bank Indonesia. Teknik pengumpulan data dilakukan dengan cara dokumentasi yaitu pengumpulan data yang diperoleh dari instansi yang terkait yang diperoleh dari publikasi resmi yang berhubungan dengan variabel yang diteliti.

Ada tiga variabel dalam penelitian ini yaituVariabel independent (Variabel bebas) dimana terdapat tiga variabel yaitu: Variabel Tingkat Inflasi $\left(\mathrm{X}_{1}\right)$ Inflasi merupakan variabel penghubung antara tingkat bunga dan pendapatan dan tabungan, ukuran dinyatakan dalam satuan persen. 
Variabel Tingkat Suku bunga $\left(\mathrm{X}_{2}\right)$ ,Suku bunga Sertifikat Bank Indonesia (SBI) adalah tingkat suku bunga yang ditentukan oleh Bank Indonesia atas penerbitan Sertifikat Bank Indonesia (SBI), ukuran dinyatakan dalam satuan persen.Variabel Produk Domestik Bruto (PDB) (X3), PDB merupakan variabel penghubung antara tingkat bunga, inflasi dan tabungan, ukuran dinyatakan dalam miliaran rupiah.

Variabel dependent (variable terikat) yaitu Variabel Tabungan (Y) Tabungan merupakan simpanan masyarakat yang penarikannya bisa dilakukan sewaktu-waktu menurut syarat-syarat tertentu yang telah ditetapkan bank, ukuran dinyatakan dalam miliar rupiah.

Ada beberapa uji yang digunakan untuk menentukan teknik yang paling tepat untuk mengestimasi regresi data panel. Antara lain Uji Statistik meliputi Pendekatan yang digunakan untuk menguji hipotesis secara statistik yaitu pendekatan signifikan. Uji ini digunakan untuk mengetahui benar tidaknya hipotesis nol. Uji hipotesis untuk mengetahui besarnya pengaruh tingkat inflasi dan tingkat suku bunga terhadap tabungan dilakukan dengan cara Regresi Linier Berganda

Untuk mengetahui pengaruh tingkat inflasi, pendapatan (PDB) dan tingkat suku bunga terhadap tabungan, digunakan analisis regresi linier berganda. Regresi ini dilakukan atas satu variabel terikat terhadap tiga variabel bebas. Hal ini bertujuan untuk mengetahui pengaruh antara variabel bebas secara keseluruhan terhadap variabel terikat.

Sistematik persamaan tersebut dapat dituliskan: $Y=f(X 1, X 2, X 3)$ Dengan $X 1=f(X 2) ; Y=a+b 1 X 1+$ $b 2 X 2+b 3 X 3+e i$ Dimana $: \mathrm{Y}=$ Tabungan $\mathrm{X} 1=$ Inflasi $\quad, \quad \mathrm{X} 2=$ Suku Bunga $(\mathrm{SBI}), \mathrm{X} 3=$ Produk domestik bruto (PDB), $\mathrm{a}=$ konstanta b1,b2 = koefisien regresi. Uji Regresi secara parsial (Uji t)

Uji $t$ atau t-test yaitu uji signifikansi trhadap masing-masing koefisien regresi diperlukan untuk mengetahui signifikan tidaknya pengaruh dari masing-masing variabel bebas (X) dan variabel terikat (Y). Berkaitan dengan uji ini, uji sinifikansi secara parsial digunakan untuk menguji hipotesis penilaian. Hipotesis yang digunakan dalam uji ini, yaitu: $H O: b l$ $=0$, berarti tidak ada pengaruh parsial 
antara variabel bebas terhadap variabel terikat. $H 0: b l \neq 0$, berarti ada pengaruh secara parsial antara variabel bebas terhadap variabel terikat. Keputusan untuk menerima atau menolak hipotesis nol dilakukan dengan membandingkan nilai t-hitung dengan ttabel. Dengan ketentuan sebagai berikut Apabila t-hitung $>$ t-tabel, maka $\mathrm{HO}$ ditolak dan $\mathrm{Hl}$ diterima, berarti pengaruh variabel bebas (X) secara parsial terhadap variabel terikat (Y) adalah signifikan.

Apabila t-hitung $<$ t-tabel, maka $H O$ diterima dan $H 1$ ditolak, berarti pengaruh variabel bebas (X) secara parsial terhadap variabel terikat (Y) adalah tidak signifikaN

Uji seluruh koefisien regresi secara serempak sering disebut dengan uji model. Oleh karena itu $F$ hitung berhubungan erat dengan koefisien determinasi $\left(R^{2}\right)$, maka pada saat melakukan uji $\mathrm{F}$ sesungguhnya menguji signifikansi koefisien determinasi $\left(R^{2}\right)$. Uji F signifikan menunjukkan bahwa variasi variabel tergantung dijelaskan sekian persen oleh variabel bebas secara bersama-sama adalah benar-benar nyata dan bukan terjadi karena kebetulan. Dengan kata lain, berapa pesen variabel tergantung dijelaskan oleh seluruh variabel bebas secara serempak (bersama-sama), dijawab oleh koefisien determinasi $\left(R^{2}\right)$, sedangkan signifikan atau tidak yang sekian persen itu dijawab oleh uji F. Berdasarkan ini, maka nilai koefisien determinasi $\left(R^{2}\right)$ dan uji $\mathrm{F}$ menentukan baik tidaknya model yang digunakan. Makin tinggi nilai koefisien determinasi $\left(R^{2}\right)$ dan signifikan, maka makin baik model tersebut.

Hipotesis yang digunakan dalam uji ini yaitu :

Apabila F-hitung $>$ F-tabel, maka $\mathrm{HO}$ dan H1 ditolak, berarti pengaruh variabel bebas (X) secara serentak terhadap variabel terikat $(\mathrm{Y})$ signifikan. Dan Apabila F-hitung < F-tabel, maka HO dan $H 1$ ditolak, berarti pengaruh variabel bebas $(\mathrm{X})$ secara serentak terhadap variabel terikat $(\mathrm{Y})$ adalah tidak signifikan,

$$
\text { Koefisien determinasi }\left(R^{2}\right)
$$
dimaksudkan untuk mengetahui tingkat ketepatan yang paling baik dalam analisa regresi, hal ini ditunjukkan oleh besarnya koefisien determinasi $\left(R^{2}\right)$ antara 0 (nol) sampai dengan 1 (satu). Jika koefisien determinasi nol berarti variabel independen sama sekali tidak berpengaruh terhadap variabel dependen. Apabila koefisien 
determinasi semakin mendekati satu, maka dapat dikatakan bahwa variabel independen berpengaruh terhadap variabel dependen. Karena variabel independen pada penelitian ini lebih dari 2, maka koefisien determinasi yang digunakan adalah Adjusted R Square (Imam Ghozali, 2001). Dari koefisien determinasi $\left(R^{2}\right)$ ini dapat diperoleh suatu nilai untuk mengukur besarnya sumbangan dari beberapa variabel $\mathrm{X}$ terhadap variasi naik turunnya variabel $\mathrm{Y}$ yang biasanya dinyatakan dalam persentase.

Uji Asumsi Klasik meliputi : Multikolinieritas Adanya korelasi yang tinggi antar variabel prediktor dinamakan multikolinieritas. Jika kasus ini terjadi dalam regresi linier, maka variabilitas $b i$ akan tidak efisien (overweight). Untuk melihat adanya multikolinieritas dapat digunakan VIF (Variance Inflation Factor) $: \mathrm{VIF}=1$ mengindikasikan tidak ada korelasi yang signifikan antar variabel prediktor; VIF > 1 mengidikasikan bahwa ada korelasi antar variabel predictor. VIF > 5 - 10 mengindikasikan bahwa ada salah satu variabel predictor merupakan fungsi dari variabel prediktor yang lain..

Heteroskedastisitas terjadi apabila varians dari setiap kesalahan pengganggu tidak bersifat konstan. Dampak yang akan ditimbulkan adalah asumsi yang terjadi masih tetap tidak berbias, tetapi tidak lagi efisien. Kondisi heteroskedastisitas sering terjadi pada data cross section, atau data yang diambil dari beberapa responden pada suatu waktu tertentu. Gejala heteroskedastisitas di uji dengan metode Glejser dengan cara menyusun regresi antara nilai absolut residual dengan variabel bebas.

Uji autokorelasi digunakan untuk melihat apakah ada hubungan linier antara error serangkaian observasi yang diurutkan menurut waktu (data time series). Uji autokorelasi perlu dilakukan apabila data yang dianalisis merupakan data time series (Gujarati, 1993).

$$
\mathrm{d}=\frac{\sum\left(e i-e_{i-1}\right) 2}{\sum e_{i}}
$$

dimana $\mathrm{d}=$ nilai Durbin Watson $\Sigma \mathrm{e}_{\mathrm{i}}=$ jumlah kuadrat sisa Nilai Durbin Watson kemudian dibandingkan dengan nilai $\mathrm{d}_{\text {-tabel. }}$ Hasil perbandingan akan menghasilkan kesimpulan seperti kriteria sebagai berikut: 1 . Jika $\mathrm{d}<\mathrm{dl}$, berarti terdapat autokorelasi positif 2 . Jika d > $(4-\mathrm{dl})$, berarti terdapat autokorelasi negative 3 . Jika du $<\mathrm{d}<(4$ $-\mathrm{dl}$ ), berarti tidak terdapat autokorelasi 
4. Jika $\mathrm{dl}<\mathrm{d}<\mathrm{du}$ atau $(4-\mathrm{du})$, berarti tidak dapat disimpulkan.

\section{PEMBAHASAN}

Berdasarkan hasil analisis data yang telah dilakukan terbukti secara signifikan bahwa inflasi, suku bunga (SBI), produk domestik bruto (PDB) secara bersama-sama berpengaruh terhadap tabungan. Dengan kata lain dapat disimpulkan bahwa dalam tabungan, para pengambil kebijakan perbankan melihat keadaan dari tingkat inflasi, suku bunga dan produk domestik bruto. Koefisien determinasi $\left(\mathrm{R}^{2}\right)$ dari model regresi yang diperoleh adalah sebesar 0,945 atau 94,5\%, hal ini menunjukkan bahwa 94,5\% keputusan mengenai kebijakan tabungan dipengaruhi oleh faktor inflasi, suku bunga (SBI) dan produk domestik bruto (PDB). Hal ini menunjukkan bahwa masih terdapat variabel lain baik itu internal maupun eksternal yang mempengaruhi tabungan yang dilakukan oleh bank umum di Indonesia yang terdapat dalam penelitian ini.

Jika ditinjau dari pengaruh parsial masing-masing variabel bebas terhadap tabungan tampak bahwa ketiga variabel yaitu suku bunga bank indonesia, inflasi, dan produk domestik bruto perlu diperhatikan oleh para pengambil kebijakan keputusan mengenai kebijakan dalam tabungan dari masyarakat yang terdapat pada bank umum di indonesia. Hal ini terlihat dari ketiga variabel bahwa dari pengaruh parsial variabel inflasi, suku bunga bank indonesia, dan produk domestik bruto (pdb) terhadap tabungan menunjukan pengaruh yang signifikan (Ha diterima).

Dengan demikian, dalam kenyataannya para pengambil kebijakan harus lebih memperhatikan lagi variabel Inflasi, suku bunga bank indonesia (SBI), dan produk domestik bruto (PDB).

\section{PENUTUP}

Berdasarkan hasil etimasi dan pembahasan hasil penelitian tentang Fluktuasi Tingkat Inflasi, Suku Bunga, dan Produk Domestik Bruto terhadap Tabungan di Indonesia tahun 2005-2010 dapat di ambil kesimpulan sebagai berikut

Setelah dilakukan rata-rata dan penjumlahan terhadap data-data yang telah di dapat dari Bank Indonesia, dapat disimpulkan bahwa terjadi peningkatan dan fluktuasi dari tahun ke tahun. Perkembangan inflasi tertinggi 
terjadi pada tahun 2006 sebesar 13.33\% dan inflasi terendah terjadi pada tahun 2009 sebesar $4.89 \%$. Sedangkan untuk suku bunga tertinggi terjadi pada tahun 2006 yaitu sebesar $11.81 \%$ dan suku bunga terendah terjadi pada tahun 2010 sebesar $7.04 \%$. Untuk produk domestik bruto, tertinggi terjadi pada tahun 2010 yaitu sebesar 64.229.175 rupiah, dan produk domestik bruto terendah terjadi pada tahun 2005 yaitu sebesar 14.118.558 rupiah. Untuk tabungan, terendah terjadi pada tahun 2005 yaitu sebesar 1.625.225 rupiah, dan tabungan tertinggi terjadi pada tahun 2010 yaitu sebesar 7.759.865 rupiah.Setelah dilakukan pengolahan, dapat diketahui bahwa $\mathrm{Y}=-0.557+0.003$ INFLASI 0.014 SUKU BUNGA+ 0.981 PDB Yang artinya bahwa inflasi berpengaruh positif terhadap tabungan sebesar 0.003 , suku bunga berpengaruh negatif terhadap tabungan sebesar -0.014 dan produk domestik bruto berpengaruh positif terhadap tabungan yaitu sebesar 0.981. Dan hasil dari nilai $\mathrm{R}^{2}$ sebesar 0,945 yang artinya 94,5 \% . Dengan demikian, tabungan dipengaruhi oleh Inflasi, Suku bunga SBI, dan Produk domestik bruto (PDB), sedangkan sisanya dijelaskan oleh variabel lain diluar model yang secara implisit tercermin pada variabel.

\section{DAFTAR PUSTAKA}

Anggraini. 2006. Pengaruh Tingkat Inflasi dan Tingkat Suku Bunga Terhadap Kurs Rupiah 20012003, Skripsi Universitas Muhammadiyah Malang.

Boediono. 1985. Ekonomi Moneter. BPFE : Yogyakarta

Diulio.A, Eugene. 1993. Uang dan Bank. Erlangga: Jakarta

Keynes.M, John. 1991. Teori Umum Mengenai Kesempatan Kerja, Bunga dan Uang. Universitas Gajah Mada: Yogyakarta

Manurung Mandala. 2004. Uang, Perbankan dan Ekonomi Moneter. Universitas Indonesia : Jakarta.

Mankiw.N, Gregory. 2003. Pengantar Ekonomi. Erlangga : Jakarta

Manullang. 1993. Ekonomi Moneter. Ghalia Indonesia: Jakarta

Nasution, Mulia.1998. Ekonomi Moneter Uang dan Bank. Djambatan. Jakarta

Nopirin. 1987. Ekonomi Moneter. BPFE : Yogyakarta.

Samuelson.A, Paul and Nordhaus.D, William. 1989. Makro Ekonomi. Erlangga : Jakarta

Sukardi, 2009. Teori Inflasi. Pusat Perbukuan Departemen Pendidikan Nasional. Jakarta 
Wigianty. 2009/06/18. wordpress.com Diakses 12-04-2012

http://aaamy24.blog.com/2011/04/18

Diakses 12-04-2012

http://www.informasiku.com/2011/04

Diakses 13-04-2012

http://jurnal-sdmku. blogspot. Com /2010/12 Diakses 13-04-2012

http://kinantiarin.wordpress.com/2011/1

0 Diakses 15-04-2012

http://abineoagus.wordpress.com/2010/

12/27 Diakses 16-04-2012 http://blog.student.uny.ac.id/ayunitasari/ 2010/12/08 Diakses 17-042012

http://bugiskha.wordpress.com/2012/04/ 14/teori-teori-suku-bunga/ Diakses 17-04-2012

http://sebrang.blogspot.com/2009/12/fa ktor-kapital-dalampembangunan.html Diakses 1704-2012

www.google.com . Business Management. Diakses 14-062012

www.bi.go.id

www.bps.go.id 